\title{
Impact of CAP's pillars on Romanian rural employment
}

\author{
Maria Vincze and Kinga Kerekes \\ Babeş-Bolyai University, Faculty of Economics and Business Administration \\ 58-60 Teodor Mihali st., 400591 Cluj-Napoca, Romania \\ e-mail:vinczefey@yahoo.com, kinga.kerekes@econ.ubbcluj.ro
}

\begin{abstract}
This paper aims to clarify the direction of change in rural employment on short- and medium term in Romania, while CAP regulations are being introduced and the global economic crisis emerges. First we put into evidence the decrease of the role of agriculture as buffer for unemployment and the poor contribution of non-agricultural activities to provide employment for rural residents. Then we analyse the main characteristics of the rural labour force. Finally we synthesize the opinions expressed by 33 consultants (working at the Offices for Agricultural Consultancy from different counties in Transylvania) about the estimated short term evolution of rural employment and the impact of CAP on Romanian rural areas.
\end{abstract}

Key words: change of agricultural structure, rural employment, impact of the Common Agricultural Policy on Romanian rural employment

\section{Introduction}

In Romania the problem of rural employment is of special importance, as $46 \%$ of the active population lives in the rural area and about $60 \%$ of the rural population are employed in agriculture. The problem could became vital because of the global economic crisis, as due to the crisis many of the young Romanians working abroad (an estimated number of 2 million people) could loose their jobs and be forced to return home, increasing the number of job seekers.

Romania is benefiting from the SAPS direct payment system and financial support for rural development measures only since 2007, from its accession to the EU. The preparation of rural areas for the EU accession by the SAPARD pre-accession programme and the gradual legal harmonisation necessary for the introduction of the Common Agricultural Policy have already impacted the structure of agriculture structure and rural development. In this paper we will concentrate more on the impact on rural employment.

\section{Material studied, area descriptions, methods, techniques}

The paper is divided in two main, complementary parts. In the first part, based on official statistical data, we analyse the evolution of the structure of agricultural holdings between 2002 and 2007, as well as the evolution of the rural workforce between 2002 and 2008 and its main characteristics in the $3^{\text {rd }}$ quarter of 2008 (the most recent period where data is available). The second part of the paper presents the opinions regarding the impact of the Common Agricultural Policy on the development of rural areas and on rural employment, expressed by consultants working at the County Offices for Agricultural Consultancy from Transylvania.

The methods used in the first part of our study are techniques of descriptive statistics: the collection and processing of statistical data. For the second part we have used a questionnaire conceived by us to collect data from a sample of agricultural consultants (Vincze \& et al., 2005); following the survey the information was synthesized.

\section{Results and discussion}

\subsection{The evolution of the structure of agricultural holdings and of non-agricultural activities}

The main subject studied in this part is the capacity of the agriculture to remain also after EU accession a buffer for unemployment, a role which it had in the transition period (Swain \& Vincze, 2001; Dumitru \& et al., 2004).

The first question concerns the process of land concentration. Based on statistical information from the General Agricultural Census 2002 and from the nation-wide survey on agriculture from 2005 and 2007, we can draw conclusions about the changes of the structure of agricultural holdings in Romania.

The overall analysis of the Romanian agriculture show a $10 \%$ decrease in the total number of farms between 2002 and 2007. An important decrease (with $22 \%$ ) of the number of small farms (less than 1 ha, not eligible for direct payments) 
Table 1. The evolution of the agricultural holdings' number and area in Romania between 2002-2007, by size of the holding and type of ownership

\begin{tabular}{|c|c|c|c|c|c|c|}
\hline \multirow{2}{*}{$\begin{array}{l}\text { Agricultural } \\
\text { holdings' } \\
\text { size }\end{array}$} & \multicolumn{4}{|c|}{ Values from 2007 reported to values from 2002 } \\
\cline { 2 - 7 } & \multicolumn{3}{|c|}{ Total holdings } & \multicolumn{2}{c|}{ Individual farms } & \multicolumn{2}{c|}{$\begin{array}{c}\text { Commercial } \\
\text { companies }\end{array}$} \\
\cline { 2 - 7 } & Number & $\begin{array}{c}\text { UAA } \\
\text { (ha) }\end{array}$ & Number & $\begin{array}{c}\text { UAA } \\
\text { (ha) }\end{array}$ & Number & $\begin{array}{c}\text { UAA } \\
\text { (ha) }\end{array}$ \\
\hline$<1$ ha & 0.78 & 0.86 & 0.78 & 0.86 & 0.26 & 0.33 \\
\hline $1-5$ ha & 0.95 & 1.00 & 0.95 & 1.00 & 0.57 & 0.58 \\
\hline $5-10$ ha & 1.37 & 1.40 & 1.38 & 1.41 & 0.63 & 0.62 \\
\hline $10-20$ ha & 1.87 & 1.96 & 1.92 & 2.00 & 0.93 & 0.94 \\
\hline $20-50$ ha & 1.70 & 1.71 & 1.78 & 1.79 & 0.95 & 1.00 \\
\hline $50-100$ ha & 1.24 & 1.29 & 1.30 & 1.35 & 1.06 & 1.12 \\
\hline$>100$ ha & 0.94 & 0.79 & 1.11 & 1.14 & 1.03 & 0.90 \\
\hline Total & 0.90 & 0.99 & 0.90 & 1.16 & 0.87 & 0.90 \\
\hline
\end{tabular}

Sources: General Agricultural Census 2002, Survey on Agriculture 2007

was registered. The number of farms of $1-5$ ha also decreased (with 5\%) and farms over $100 \%$ as well (with 6\%). In the same time the number of farms of 5-100 ha increased, the highest increase (with $87 \%$ ) being registered for farms of 10-20 ha, followed by farms of 20-50 ha (with 70\%). We can clearly observe the concentration of parcels into bigger farms, mainly of 10-20 ha and 20-50 ha. In the case of individual agricultural holdings, the number of farms under 5 ha decreased and the number of those above 5 ha increased; the highest increase in number was registered for farms of 10-20 ha. In the case of commercial companies farms with more than 100 ha are dominant (63\%); these work about $97 \%$ of the land used by all commercial farms.

We can't conclude that the introduction of the Single Area Payment Scheme directly caused the concentration of land in larger farms, as direct payments were applied first in March 2008. However, as the examples from the more developed EU countries demonstrate, we can consider that land concentration is a middle- and long-time process.

From the perspective of the Romanian agriculture's competitiveness the fact, that between 2002 and 2007 the number of farms with less than 5 ha decreased with more than half a million $(568,383)$, can be considered as a positive development. On the other hand this situation raises some social problems, as subsistence farming ensured everyday existence for many rural residents (Bezemer \& Davis, 2002; Davis \& Cristoiu, 2002; Sandu, 2003). Therefore the need to provide jobs in the rural areas, mainly in non-agriculture has increased.

In Romania the privatization of state agriculture created the class of big landowners or land concessionaires that operate several thousands of hectares of land (P.I. Otiman, 2008). The concentration of land into big, commercial and generally wellequipped farms reduces the capacity of agriculture to provide jobs for low-educated persons (Vincze \& al., 2005).

Concentration can also be observed in cattle-breeding. In 2002 around $77 \%$ of the cattle were registered in farms with less than 5 ha and for 2007 this share decreased to around $65 \%$. In the same time the share of cattle in farms over 20 ha increased from $5.8 \%$ to $9.7 \%$. This concentration accelerated after the introduction of CAP subventions for milk and cattle and also because EU hygienic norms were step by step made compulsory. The decrease of the number of heads with 431,238 in farms smaller than 5 ha in the period 2002-2007 put into evidence the reduction of an important source of subsistence for small farms.

From the perspective of employment, giving up cattlebreeding in subsistence farms means the increase of underemployment of individual farmers and a decrease of their income, which again lead us to the conclusion that nonagricultural jobs has to be created in order to avoid the depopulation of the villages and to stop the extension of unused agricultural areas. In the present situation, when about 1.7 million agricultural holdings are smaller than 1 ha and 1.8 million have between 1-5 ha, underemployment in subsistence farms is a reality, which impose rural job creation (Kerekes, 2007a; Vincze, 2007).

Even if we observe an increase in the dimension of the holdings, the economic scale of market sale is still very low. Statistical figures show that $79 \%$ of agricultural holdings were less than 1 ESU in 2007, meaning that only 850 thou farms $(21 \%)$ have a gross margin above 1 ESU.

The share $(8.3 \%)$ and the evolution of the number of the agricultural holdings carrying out non-agricultural activities

Table 2. The structure of cattle-breeding farms in Romania, in 2002 and 2007

\begin{tabular}{|c|c|c|c|c|c|c|c|c|}
\hline \multirow{2}{*}{$\begin{array}{l}\text { Size of } \\
\text { holding }\end{array}$} & \multicolumn{5}{|c|}{2002} & \multicolumn{3}{|c|}{2007} \\
\hline & $\begin{array}{l}\text { Cattle } \\
\text { heads }\end{array}$ & $\%$ & $\begin{array}{c}\text { Utilised } \\
\text { agricultural } \\
\text { area (ha) }\end{array}$ & $\begin{array}{c}\text { Cattle } \\
\text { heads } \\
\text { per UAA }\end{array}$ & $\begin{array}{l}\text { Cattle } \\
\text { heads }\end{array}$ & $\%$ & $\begin{array}{c}\text { Utilised } \\
\text { agricultural } \\
\text { area (ha) }\end{array}$ & $\begin{array}{c}\text { Cattle } \\
\text { heads per } \\
100 \text { ha UAA }\end{array}$ \\
\hline$<1$ ha & 572232 & 19.93 & 758815.08 & 0.7541 & 365104 & 13.36 & 649530.35 & 56.21 \\
\hline $1-5$ ha & 1626081 & 56.64 & 4180568.33 & 0.3890 & 1401971 & 51.29 & 4179874.35 & 33.54 \\
\hline $5-10$ ha & 358481 & 12.49 & 1440944.55 & 0.2488 & 502891 & 18.40 & 2017538.56 & 24.93 \\
\hline $20-50$ ha & 40240 & 1.40 & 281172.09 & 0.1431 & 94783 & 3.47 & 481253.26 & 19.70 \\
\hline $50-100$ ha & 18053 & 0.63 & 258042.66 & 0.0700 & 44819 & 1.64 & 333053.59 & 13.46 \\
\hline$>100$ ha & 109728 & 3.82 & 6540069.84 & 0.0168 & 125781 & 4.60 & 5167568.48 & 2.43 \\
\hline Total & 2870782 & 100.00 & 13930710.10 & 0.2061 & 2733557 & 100.00 & 13753046.49 & 19.88 \\
\hline
\end{tabular}

Sources: General Agricultural Census 2002, Survey on Agriculture 2007 
Table 3. The changes of number of agricultural holdings carrying out non-agricultural activities in Romania between 2002-2007, by size of the holding and type of ownership

\begin{tabular}{|l|c|c|c|c|c|c|c|c|c|}
\hline \multirow{2}{*}{$\begin{array}{l}\text { Type of } \\
\text { non-agricultural } \\
\text { activities }\end{array}$} & \multicolumn{3}{|c|}{$\mathbf{2 0 0 5 / 2 0 0 2}$} & \multicolumn{3}{c|}{$\mathbf{2 0 0 7 / 2 0 0 5}$} & \multicolumn{3}{c|}{$\mathbf{2 0 0 7 / 2 0 0 2}$} \\
\cline { 2 - 11 } & $\begin{array}{l}\text { Indiv. } \\
\text { farms }\end{array}$ & $\begin{array}{c}\text { Com. } \\
\text { comp. }\end{array}$ & Total & $\begin{array}{c}\text { Indiv. } \\
\text { farms }\end{array}$ & $\begin{array}{c}\text { Com. } \\
\text { comp. }\end{array}$ & $\begin{array}{c}\text { Total } \\
\text { farms }\end{array}$ & Indiv. & $\begin{array}{c}\text { Com. } \\
\text { comp. }\end{array}$ & Total \\
\hline Food processing & 6.11 & 0.55 & 6.04 & 0.67 & 0.71 & 0.67 & 4.08 & 0.39 & 4.04 \\
\hline $\begin{array}{l}\text { Wood processing } \\
\text { +other proc. }\end{array}$ & 0.73 & 0.27 & 0.72 & 1.10 & 0.65 & 1.10 & 0.81 & 0.18 & 0.79 \\
\hline Agro-tourism & 1.75 & 0.37 & 1.66 & 0.74 & 1.24 & 0.74 & 1.29 & 0.45 & 1.24 \\
\hline Services & 2.98 & 1.27 & 2.95 & 0.09 & 0.15 & 0.09 & 0.26 & 0.19 & 0.26 \\
\hline $\begin{array}{l}\text { Production of } \\
\text { non-conv. energy }\end{array}$ & 2.33 & 0.50 & 2.16 & 0.93 & 0.88 & 0.93 & 2.18 & 0.44 & 2.02 \\
\hline Handicraft & 0.63 & 0.27 & 0.63 & 0.87 & 1.27 & 0.87 & 0.55 & 0.35 & 0.55 \\
\hline Aquaculture & 2.47 & 0.23 & 1.88 & 1.55 & 0.94 & 1.53 & 3.83 & 0.21 & 2.88 \\
\hline Other activities & 1.87 & 0.23 & 1.74 & 0.63 & 0.55 & 0.63 & 1.17 & 0.13 & 1.09 \\
\hline TOTAL & 4.49 & 1.23 & 4.41 & 0.53 & 0.33 & 0.53 & 2.39 & 0.40 & 2.35 \\
\hline
\end{tabular}

Sources: General Agricultural Census 2002, Surveys on Agriculture 2005 and 2007

\subsection{The evolution of the structure of the rural workforce between 2002 and 2008}

In the next part we will analyse the characteristics of the rural labour force. First, we observe the different evolution of the urban and rural labour force in the analysed period.

The favourable macroeconomic environment from Romania in the period 2002-2008 (about 5\%-9\% real growth of GDP and decreasing inflation) had a different impact on the labour force market in the urban and rural areas.

Besides that activity rates' evolution had a different direction in urban areas (increasing) than in the
$(363,377$ in 2002) is also not encouraging. In the period 2002-2007 the extension of non-agricultural employment could not compensate the decrease of agricultural employment. Between 2002-2005, due to the SAPARD programme, an important increase of the number of individual holdings carrying out food processing or agro-tourism activities can be observed. The number of service provider individual holdings tripled, of those producing non-conventional energy and dealing with aquaculture increased with around 2.5 times. The process slowed down in the period 2005-2007. This slowdown is on one hand explained by the fact that EU norms and standards were increasingly applied, which raised investment costs, therefore the necessary amount of own contribution as well. On the other hand conditions for sale also changed: small processing units were not able to meet the requirements set by of big commercial chains and the strong Romanian currency was also facilitating import (Toderoiu, 2005; Sofer \& Bordânc, 2006).

Between 2007 and 2013, even though and important amount (around 8 billion euro from EARDF) can be used for rural development and, within $\mathrm{RD}$, for the development of rural SME's, we do not foresee a big increase in the number of rural SME's because of the effects of the global economic crisis, which restrict credit opportunities and decrease local demand.
Table 4. Romanian population, by economic activity and area, in 2002 and 2008

\begin{tabular}{|c|c|c|c|c|c|c|c|}
\hline \multirow{3}{*}{$\begin{array}{l}\text { Area / } \\
\text { Period }\end{array}$} & \multicolumn{3}{|c|}{ Economically active persons } & \multirow{2}{*}{$\begin{array}{c}\text { In- active } \\
\text { persons }\end{array}$} & \multirow{2}{*}{$\begin{array}{c}\text { Activity } \\
\text { rate }\end{array}$} & \multirow{2}{*}{$\begin{array}{c}\text { Employment } \\
\text { rate }\end{array}$} & \multirow{2}{*}{$\begin{array}{c}\text { ILO } \\
\text { unempl. rate }\end{array}$} \\
\hline & Total & Employed & ILO & & & & \\
\hline & thou.pers. & thou.pers & $\begin{array}{l}\text { unemloyed } \\
\text { thou.pers }\end{array}$ & thou.pers & $\%$ & $\%$ & $\%$ \\
\hline \multicolumn{8}{|l|}{ URBAN } \\
\hline 2002 Q III & 5259 & 4681 & 578 & 6320 & 53.9 & 48 & 11 \\
\hline 2008 Q III & 5503 & 5143 & 360 & 6305 & 53.9 & 50.4 & 6.5 \\
\hline \multicolumn{8}{|l|}{ RURAL } \\
\hline 2002 Q III & 5127 & 4927 & 200 & 5089 & 62.1 & 59.7 & 3.9 \\
\hline 2008 Q III & 4675 & 4484 & 191 & 5021 & 58.2 & 55.8 & 4.1 \\
\hline
\end{tabular}

Source: Labour force in Romania. Employment and Unemployment in the $3^{\text {rd }}$ quarter 2008

Table 5. Activity rate of the population aged 15 years and over, by age group and area, in 2002 and 2008

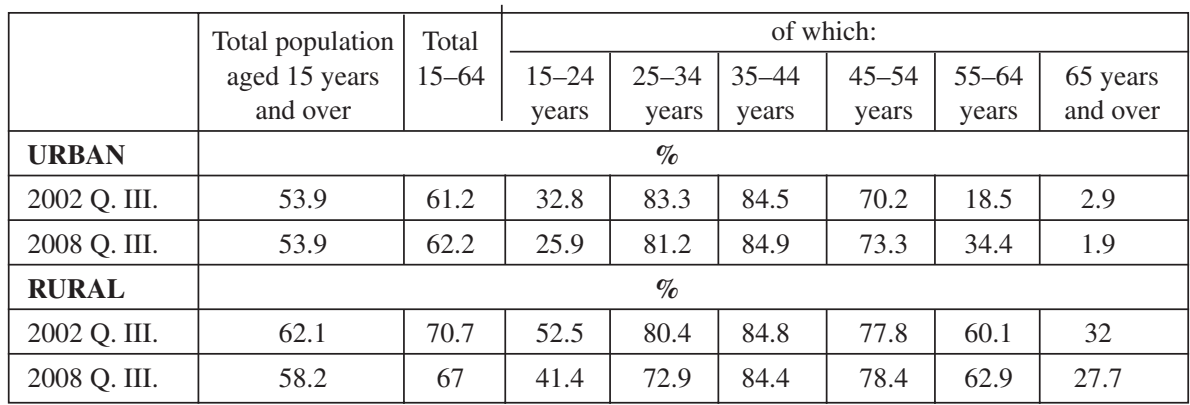

Source: Labour force in Romania. Employment and Unemployment in the $3^{\text {rd }}$ quarter 2008 rural areas (decreasing), we can also notice that activity rates decreased for young age-groups (15-34 years). The evolution of unemployment rate between 2002 and 2008 was also unfavourable in the rural area.

After this short comparative description of the urban and rural labour force market dynamics, we will analyse in more detail the present characteristics ( $3^{\text {rd }}$ quarter 2008) of the Romanian rural labour force. 
Table 6. ILO unemployment rate, by age groups and area,

\begin{tabular}{|l|c|c|c|c|c|c|}
\hline & \multirow{6}{*}{ Total } & \multicolumn{5}{|c|}{ of which: } \\
\cline { 3 - 7 } & & $\begin{array}{c}15-24 \\
\text { years }\end{array}$ & $\begin{array}{c}25-34 \\
\text { years }\end{array}$ & $\begin{array}{c}35-44 \\
\text { years }\end{array}$ & $\begin{array}{c}45-54 \\
\text { years }\end{array}$ & $\begin{array}{c}55-64 \text { years } \\
\text { and over }\end{array}$ \\
\hline URBAN & \multicolumn{7}{|c|}{$\%$} \\
\hline 2002 Q. III. & 11 & 29.1 & 10.5 & 8 & 7.2 & 3.4 \\
\hline 2008 Q. III. & 6.5 & 24.8 & 5.3 & 5 & 4.9 & 3.1 \\
\hline RURAL & \multicolumn{7}{|c|}{$\%$} \\
\hline 2002 Q. III. & 3.9 & 11.6 & 4.5 & 3.4 & 2.3 & 0.1 \\
\hline 2008 Q. III. & 4.1 & 14.8 & 4.3 & 3.1 & 2.3 & 0.9 \\
\hline
\end{tabular}

Source: Labour force in Romania. Employment and Unemployment in the $3^{\text {rd }}$ quarter 2008

\begin{tabular}{|c|c|c|c|c|c|c|c|}
\hline \multirow{3}{*}{ Age group } & \multirow{2}{*}{$\begin{array}{c}\text { Total } \\
\text { population }\end{array}$} & \multicolumn{3}{|c|}{ Economically active persons } & \multirow{2}{*}{$\begin{array}{l}\text { Activity } \\
\text { rate }\end{array}$} & \multirow{2}{*}{$\begin{array}{l}\text { Employ- } \\
\text { ment rate }\end{array}$} & \multirow{2}{*}{$\begin{array}{c}\text { ILO } \\
\text { unemploy- } \\
\text { ment rate }\end{array}$} \\
\hline & & Total & Employed & $\begin{array}{c}\text { ILO } \\
\text { unemployed }\end{array}$ & & & \\
\hline & (pers.) & (pers.) & (pers.) & (pers.) & $(\%)$ & $(\%)$ & $(\%)$ \\
\hline \multicolumn{8}{|l|}{ RURAL } \\
\hline 15 years and over & 8030518 & 4675602 & 4484463 & 191139 & 58.2 & 55.8 & 4.1 \\
\hline young (15-24 years) & 1369254 & 566938 & 483206 & 83732 & 41.4 & 35.3 & 14.8 \\
\hline adults (15-64 years) & 6230976 & 4176374 & 3985459 & 190915 & 67 & 64 & 4.6 \\
\hline aged (55-64 years) & 1067010 & 671433 & 661127 & 10313 & 62.9 & 62 & 1.5 \\
\hline
\end{tabular}

Source: Labour force in Romania. Employment and Unemployment in the $3^{\text {rd }}$ quarter 2008 in 2002 and $2008(\%)$

Table 7. The labour force in Romania, $3^{\text {rd }}$ quarter 2008

is the unfavourable distribution of labour force by economic activities. In present Romanian economy, the lowest level of labour productivity is in agriculture, where more than $61 \%$ of rural labour force is employed.

\subsection{The impact of CAP on the development of rural areas and on rural employment}

In the last part of this paper we summarize the subjective opinions regarding the impact of the Common Agricultural Policy on the development of rural areas and on rural employment, expressed by consultants working at the County Offices for Agricultural Consultancy. The questionnaires, completed by 33 consultants from different parts of the NUTS1 macro-region no. 1 (formed by the NUTS2 regions North-West and Center), reveal the fact that CAP is only seen as a source of support for farms and the potential advantage of the huge single market is completely neglected, even by persons who are local experts in agriculture. CAP is considered an opportunity for big commercial farms and a threat for subsistence farms.

The experts mostly agree on that

Figures from table 7 show a relatively positive picture of the situation of rural employment, but a more detailed analysis put into evidence some important problems.

Table 8. The rural labour force in Romania, by age groups, $3^{\text {rd }}$ quarter 2008

\begin{tabular}{|l|c|c|c|}
\hline \multirow{2}{*}{ Age group } & $\begin{array}{c}\text { Activity } \\
\text { rate }\end{array}$ & $\begin{array}{c}\text { Employment } \\
\text { rate }\end{array}$ & $\begin{array}{c}\text { ILO } \\
\text { unemployment rate }\end{array}$ \\
\cline { 2 - 4 } & $(\%)$ & $(\%)$ & $(\%)$ \\
\hline RURAL & $\mathbf{5 8 . 2}$ & $\mathbf{5 5 . 8}$ & $\mathbf{4 . 1}$ \\
\hline 15-19 years & 25.7 & 19.8 & 22.8 \\
\hline 20-24 years & 56.3 & 49.9 & 11.3 \\
\hline 65 years and over & 27.7 & 27.7 & - \\
\hline
\end{tabular}

Source: Labour force in Romania. Employment and Unemployment in the $3^{\text {rd }}$ quarter 2008

The relatively high level of activity, employment and unemployment rate in the 15-19 and 20-24 years age groups on one hand, and of the 65 years and over age group on the other hand illustrate the main specificities of the Romanian rural labour force. We can conclude immediately that education level will remain low in the near future, as an important share of the 15-19 years old are not attending school. It is evident, that many young rural persons haven't got adequate education and skills to meet job requirements (Kerekes, 2007b).

Another specificity of the rural employment the number of small subsistence farms will continue to decrease in the near future and that land concentration, as well as market orientation of small producers will intensify. Experts also foresee the increase of the income of agricultural producers, mostly through the extension of complementary activities, like rural tourism. There is a growing demand for extension services, because of the implementation of the SAPS system and of the different rural development measures. The County Offices for Agricultural Consultancy offer free consultancy services on these issues.

Opinions regarding the evolution of agricultural production and rural employment are diverse and they differ from county to county. The seasonal external migration of the rural workforce will continue to increase according to many respondents. Some experts foresee a small increase of the rural unemployment rate.
Table 9. Rural population, by age groups and level of education

\begin{tabular}{|l|r|r|r|r|r|r|r|}
\hline & $\begin{array}{r}\text { Total } \\
\text { (persons } \\
\text { and\%) }\end{array}$ & $\begin{array}{r}15-24 \\
\text { years }\end{array}$ & $\begin{array}{r}25-34 \\
\text { years }\end{array}$ & $\begin{array}{r}35-44 \\
\text { years }\end{array}$ & $\begin{array}{r}45-54 \\
\text { years }\end{array}$ & $\begin{array}{r}55-64 \\
\text { years }\end{array}$ & $\begin{array}{r}\text { 65 years } \\
\text { and over }\end{array}$ \\
\hline RURAL & $\mathbf{9 6 9 6 7 4 0}$ & $\mathbf{1 3 6 9 2 5 4}$ & $\mathbf{1 4 0 3 8 5 1}$ & $\mathbf{1 3 3 8 0 6 9}$ & $\mathbf{1 0 5 2 7 9 2}$ & $\mathbf{1 0 6 7 0 1 0}$ & $\mathbf{1 7 9 9 5 4 2}$ \\
\hline High (\%) & 1,9 & 1.4 & 4.7 & 2.1 & 2.9 & 2.5 & 0.9 \\
\hline Medium (\%) & 34,6 & 40.8 & 55.6 & 72.8 & 56.4 & 30.5 & 6.9 \\
\hline Low (\%) & 63,5 & 57.8 & 39.7 & 25.1 & 40.8 & 67.0 & 92.2 \\
\hline of which & 1800389 & 100506 & 58198 & 33561 & 60585 & 190978 & 932797 \\
\hline Primary (\%) & 18,6 & 7.3 & 4.1 & 2.5 & 5.8 & 17.9 & 51.8 \\
\hline No education (\%) & 15,4 & 1.8 & 2.1 & 1.3 & 1.4 & 1.4 & 9.7 \\
\hline
\end{tabular}

Source: Labour force in Romania. Employment and Unemployment in the $3^{\text {rd }}$ quarter 2008 
Table 10. Structure of employment, by age groups and sectors of economic activity

\begin{tabular}{|c|c|c|c|c|c|c|c|c|}
\hline \multirow[b]{2}{*}{$\begin{array}{l}\text { Economic } \\
\text { activity }\end{array}$} & \multirow[b]{2}{*}{$\begin{array}{c}\text { Total } \\
\text { employment }\end{array}$} & \multicolumn{3}{|l|}{ Total } & \multicolumn{4}{|c|}{ ge groups } \\
\hline & & $\begin{array}{l}15-64 \\
\text { years }\end{array}$ & $\begin{array}{l}15-24 \\
\text { years }\end{array}$ & $\begin{array}{l}25-34 \\
\text { years }\end{array}$ & $\begin{array}{l}35-44 \\
\text { years }\end{array}$ & $\begin{array}{l}45-54 \\
\text { years }\end{array}$ & $\begin{array}{l}55-64 \\
\text { years }\end{array}$ & $\begin{array}{l}65 \text { years } \\
\text { and over }\end{array}$ \\
\hline & (persons and $\%$ ) & $(\%)$ & $(\%)$ & $(\%)$ & $(\%)$ & $(\%)$ & $(\%)$ & $(\%)$ \\
\hline RURAL & 4484463 & 88.9 & 10.8 & 21.8 & 23.5 & 18 & 14.8 & 11.1 \\
\hline Agriculture & $2748251(61.3 \%)$ & 82 & 9.5 & 17.3 & 17.8 & 16.6 & 20.8 & 18 \\
\hline Industry & $928241(20.7 \%)$ & 99.9 & 14.4 & 30.2 & 32.1 & 19.1 & 4.1 & 0.1 \\
\hline Services & $807971(18 \%)$ & 99.7 & 10.8 & 27.6 & 33.1 & 21.8 & 6.4 & 0.3 \\
\hline
\end{tabular}

Source: Labour force in Romania. Employment and Unemployment in the $3^{\text {rd }}$ quarter 2008

Young rural people have low interest for carrying on the activity of the inherited family farm, they prefer to rent or to sell the farm and try to find a job in the cities or abroad. One third of the respondents, mostly those from Harghita and Satu Mare counties, foresee a small increase, and during the global economic crisis this seems to be a more realistic view.

Many experts see the future of agricultural employment connected to the growing SAPS and to rural development measures, as these sustain employment in agricultural production. Others think that the differences among agricultural and non-agricultural income levels, as well as the availability of non-agricultural jobs are decisive factors for staying or not in agriculture. In the opinion of the experts, direct payments provided within the CAP are mostly used for inputs and partly for household consumption. Most respondents consider aging of the villages will speed up, but opinions differ as regards future commuting patterns and the evolution of the number of SME's.

This survey shows that the introduction of the CAP has already some effects on the Romanian agriculture and on rural areas, but a more extensive analysis can only be carries out when the amount of direct payments will grow and when all rural development measures will be implemented.

\section{Conclusion}

We can state as a general conclusion that in Romania the role of agricultural employment is decreasing and that local non-agricultural labour market is limited, at both of demand and supply side. The emerging global economic crisis will, on one hand, force to return those working abroad and, on another hand, will decrease work opportunities from the cities. The comparative analysis of the urban and rural labour force put into evidence that the present structure (by age and education level) of the rural active population is unfavourable and that this unfavourable structure will be maintained in the future, too. If urgent measures will not be taken for a better education of children from the rural areas, there will be no chance to equilibrate the rural labour market.

The critical points of the Romanian rural employment are represented by the low education level of the 15-24 years old rural population, combined with a relatively high incomeexpectation and the limited opportunities for non-agricultural jobs. The analysis of the rural labour market is strongly connected to the territorial characteristics of the rural areas; therefore identification of the local labour-market problems can be a starting point for reaching the solution.

The conclusions of this paper are intermediate results of the RuralJobs FP7 research project, financed by the EC.

\section{References}

Bartus, T. (2008): Városok elérhetősége és a falusi munkanélküliség, in: Balogh, P. \& al. (eds.) (2008): 60 éves a Közgazdaságtudományi Egyetem, Aula, Budapest

Bezemer, D., J. Davis (2002): The rural non-farm economy in Romania: overview of findings, Natural Resource Institute Report No. 2730

COM (2006): 857 final: Employment in rural areas: closing the jobs gap

Davis, J., A. Cristoiu (2002): Patterns of rural non-farm diversification and employment in Romania: A county level analysis, Natural Resources Institute Report No. 2639

Dumitru M. \& al. (2004): Rural Development and the Reform of Romanian Agriculture, Bucharest: European Institute of Romania, Working Paper No. 10-11

Government of Romania (2007): Sectoral Operational Programe Human Resources Development 2007-2013

Government of Romania (2008): National Rural Development Programme of Romania 2007-2013

Kerekes, K. (2007a): Employment opportunities for people living in rural areas, in: Proc. Int. Conf. Competitiveness and European Integration, Regional and Rural Economics, 26-27 October 2007, Alma Mater, Cluj-Napoca

Kerekes, K. (2007b): Occupational choices of rural youth, in: Proc. Int. Conf. Competitiveness and European Integration, Regional and Rural Economics, 26-27 October 2007, Alma Mater, Cluj-Napoca

Kerekes, K. (2008): Rural Entrepreneurship in Romania. Case Study: Cluj County, in: Proc. Int. Conf. Entrepreneurship and Economic Growth, 28-29 March 2008, Abel, Cluj-Napoca

Kerekes, K., A. Fieldsend (2008): Contrasting Rural Employment Problems across the EU, in: RSA Winter Conference - Working Regions, 28 November 2008, London

OECD (2006): The new rural paradigm: policies and governance, OECD, Paris

Otiman, P.I. (2008): Sustainable development strategy of agriculture and rural areas in Romania on medium and long termrural Romania XXI, in: Agricultural Economics and Rural Development, New series, year V, no. 1-2

Sandu, D. (2003): România rurală de azi: ocupare neagricolă şi navetism, Bucureşti: Comisia Antisărăcie şi Promovare a Incluziunii Sociale

Sofer, M., F. Bordânc (2006): Oportunitãpi, constrângeri şi pluriactivitate în România rurală în timpul perioadei de tranziţie: observaţii preliminare, in: Economie agrară şi dezvoltare rurală, no. 9-10 
Swain, N., M. Vincze (2001): Agricultural Restructuring in Transylvania in the Post-Communist Period, in: D. Light \& D. Phinnemore (ed.) Post-Communist Romania. Coming to Terms with Transition, New York: Palgrave Publishers

Toderoiu F. (2005): Romanian agri-food sector convergence with the macroeconomic performance criteria of the European Union. Agricultural economics and rural development, Romanian Academy, National Institute of Economic Research, Institute of Agricultural Economics, no. 2

Vincze, M. \& al. (2005): Impact of CAP on Rural Employment. Case study: Cluj County, in: Proc. Int. Conf. The Impact of European Integration on the National Economy. Regional and Rural Economics, Risoprint, Cluj-Napoca
Vincze, M. (2007): The Key Problems of Romanian Rural Development after EU Accesion, in: Proc. Int. Conf. Competitiveness and European Integration, Regional and Rural Economics, 26-27 October 2007, Alma Mater, Cluj-Napoca

Vincze, M. (2005): Románia vidékpolitikája felül- és alulnézetből, University Press, Pécs

*** 2002 General Agricultural Census, NIS, Bucharest

*** Labour Force in Romania, Employment and Unemployment, 2000-2008, NIS Bucharest

*** Surveys on Agriculture 2005-2007, NIS, Bucharest 